\title{
Intra - Urban Traffic Characteristics Of Ikot Ekpene - An Emerging Urban Centre In Akwa Ibom State, Nigeria
}

\author{
Ekong E. Daniel, Ph.D \\ Centre for General Studies \\ Akwa Ibom State University, Nigeria \\ Joseph Udoh, Ph.D \\ Department of Geography \& Natural Resources Management. \\ University of Uyo, Nigeria \\ Reuben K. Udo \\ Emeritus Professor \\ Akwa Ibom State University, Nigeria
}

\begin{abstract}
In recent years, many municipal authorities in the developing region of the world have been grappling with traffic related challenges such as increasing rates of traffic accidents and traffic confusion along the major urban roads and streets of their municipalities. There are needs for efficient transportation system to enhance safe and smooth movements of people and goods within the municipalities. This cannot be achieved without rational planning decisions and rational planning decisions cannot be attained without the basic understanding of materials. The materials for transportation planning include not only the physical ways and the vehicles with which people and goods move about but also the volume and characteristics of traffic. The knowledge of these essential materials was lacking in Ikot Ekpene - an emerging urban centre in Akwa Ibom State. The aim of the study was to ascertain the volume and characteristics of traffic in the city. Data were generated through the manual traffic count at three (3) traffic cordon points (TCP) carefully determined. The survey was conducted simultaneously at the three traffic cordon points. Traffic data were generated on the different week day during the hours of 8am - 5pm at hourly intervals. A total of $\mathbf{1 8 9}$ field data sheets were completed and returned and used in the analysis. The traffic was categorized under: (i) Pedestrian, (ii) Bicycle, (iii) Motor cycle, (iv) Tricycle, (v) Buses and Cars, (vi) Heavy duty and trucks. The study revealed the dominance of motorcycle in the traffic flow with a total weekly volume of $49292(69.94 \%)$, followed by Buses and cars $14324(20.32 \%) ;$ Pedestrian 5504 (7.8\%); Heavy duty vehicles/trucks $1221(1.73 \%)$; Tricycle $70(0 \%)$; and Bicycle 69(0\%). Limiting the operation of commercial motorcyclists, construction of bye-passes, relocation of public and private commercial motor parks and upgrading of the existing urban roads and streets to provide the pedestrian walk ways were recommended.
\end{abstract}

Keywords: Intra-urban, Traffic, Ikot Ekpene, Akwa Ibom State, Nigeria.

\section{INTRODUCTION}

The world is undergoing the largest wave of urban growth in history. More than half of the world's population (approx. 3.7billion) now lives in towns and cities and by 2030 this number is expected to swell to about 5 billions. Much of this urbanization is developing in Africa and Asia, bringing huge social, economic and environmental transformation (World Bank, 2016). In Nigeria were the population is currently estimated at 178.507 million, approximately $50 \%$ of these Nigerians are urban dwellers, and with an annual urbanization growth rate of $3.5 \%$ the 
country is expected to experience considerable social, economic and environmental transformation associated with rapid urbanization. One major sector that will receive severe pressure from rapid urban growth is the transportation sector. At present, urban dwellers in Nigeria are already facing myriads of problems ranging from insecurity of lives and property, traffic related problems, health, housing, poverty and many others (Daniel \& Ituen, 2013a). Eluwa, et al (2012) have observed that whether we think of welfare services or employment opportunities, the urban system in Nigeria today is already proving inadequate in providing the type of social order that the country desires.

Ikot Ekpene, the focal point of this study is the second largest urban centre in Akwa Ibom State. It has estimated population of 230,000 (Wikipedia, 2016). In recent years, the urban centre has been grappling with traffic related challenges such as increasing rates of traffic accidents and traffic confusion along the major roads and some streets in the city. One major function of the spatial structure of any human settlement is to facilitate the movement of people and goods within the settlement. Efficient transportation system together with good condition and networks enhance the movement of people within any urban centre (Daniel \& Ituen, 2013 ${ }^{\mathrm{b}}$ ). To be sure, no smooth movement of people and goods in a complex urban system can be achieved without rational planning decisions. Basic to any planning is an understanding of materials and the materials of the transportation planner include not only the physical ways and the vehicles used in carrying people and goods, but also the volume of traffic generated by the various categories of vehicles (Daniel \& Umoren, 2013). The knowledge of these essential materials is presently lacking in the study area. This study seeks to fill the gap.

\section{AN OVERVIEW OF THE STUDY AREA}

Ikot Ekpene city is known throughout Nigeria as "The Raffia City" and locally as "IK". The city is located between latitudes $5^{\circ} 10^{1} 15^{\mathrm{ll}}$ and $5^{\circ} 11^{\mathrm{l}} 45^{\mathrm{ll}}$ North and longitudes $7^{\mathrm{o}} 42^{\mathrm{l}} 00^{\mathrm{ll}}$ and $7^{\mathrm{o}} 43^{\mathrm{l}}$ $45^{\mathrm{ll}}$ East. It is the headquarters of Ikot Ekpene Local Government Area of Akwa Ibom State, Nigeria (see Fig. 1). It happens to be the first urban centre selected in 1951 by the colonial government, used to experiment the local government system when Major Alderton was the district officer. It is the political and cultural capital of the Annang ethnic group (Nair, 1972). It is located on the Nigerian highway A2, the second South to North trunk road that runs parallel from the coast of Oron through Uyo, the capital of Akwa Ibom State, Aba, Owerri Enugu - Makurdi - Kano.

The city is a regional centre of commerce that exports palm products especially palm oil, kernels, raffia product including raffia fibers and its sweet wine to various parts of the country. The major food crops produced include yams, cassava, taro and corn. Ikot Ekpene was chosen by the British Colonial Administration to serve as the headquarters of Ikot Ekpene District and Ikot Ekpene Division made up of Ikot Ekpene, Otoro, Central Annang and Ikono Districts. The core area of Ikot Ekpene is made up of the villages of Ikot Ekpene, Ikot Obong Edong, Uruk Uso, Abikpo, and Nkap which were formerly district settlements separated by forests and farmlands. Its selection in 1912 or earlier as administrative headquarters led to its growth.. In 1937, the colonial administration built the main market and separated those who sold imported European goods from indigenous articles. It became divisional headquarters and seat of Ikot Ekpene county council. Today, it is a municipal centre in Akwa Ibom State - serving as a Local Government Headquarters of Local Governement Area of the same name.

\section{AIM AND OBJECTIVES OF THE STUDY}

The main aim of the study was to ascertain the intra-urban traffic characteristics of Ikot Ekpene urban centre. In order to achieve this aim, the following objectives were set out:

1. To determine the volume and characteristics of the intra-city traffic. 
2. To identify the spatial variation of the intra-city traffic volume.

3. To identify the temporal variation of the city traffic volume

4. To ascertain the traffic flow patterns of the city.

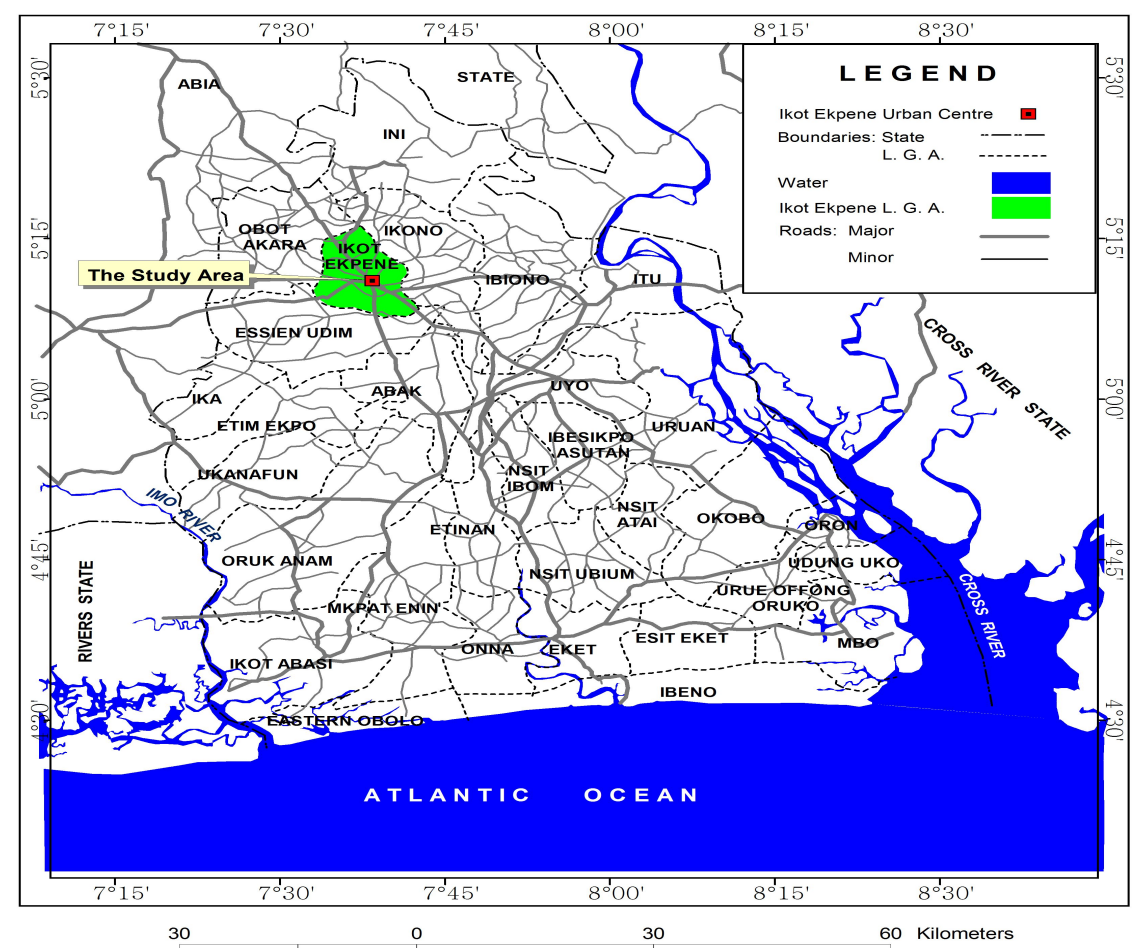

Fig. 1: Akwa lbom State, Nigeria showing the Location of Ikot Ekpene - The Study Location

\section{AN OVERVIEW OF URBAN TRANSPORT SYSTEM}

In categorizing traffic in a study region, Daniel (2012) identified three basic types of traffic movements as follows:

i. External traffic;

ii. Internal traffic; and

iii. Through traffic.

Internal traffic or intra-city traffic movements are those that originate and end within the city. External traffic or inter-city traffic has at least one end of each movement outside the city of origin. While Through traffic or inter-state traffic has both origins and destinations outside the city (see Fig 2). However, this study of Ikot Ekpene is limited to intra-city traffic, that is traffic generated and attracted among the different sections of Ikot Ekpene township. 


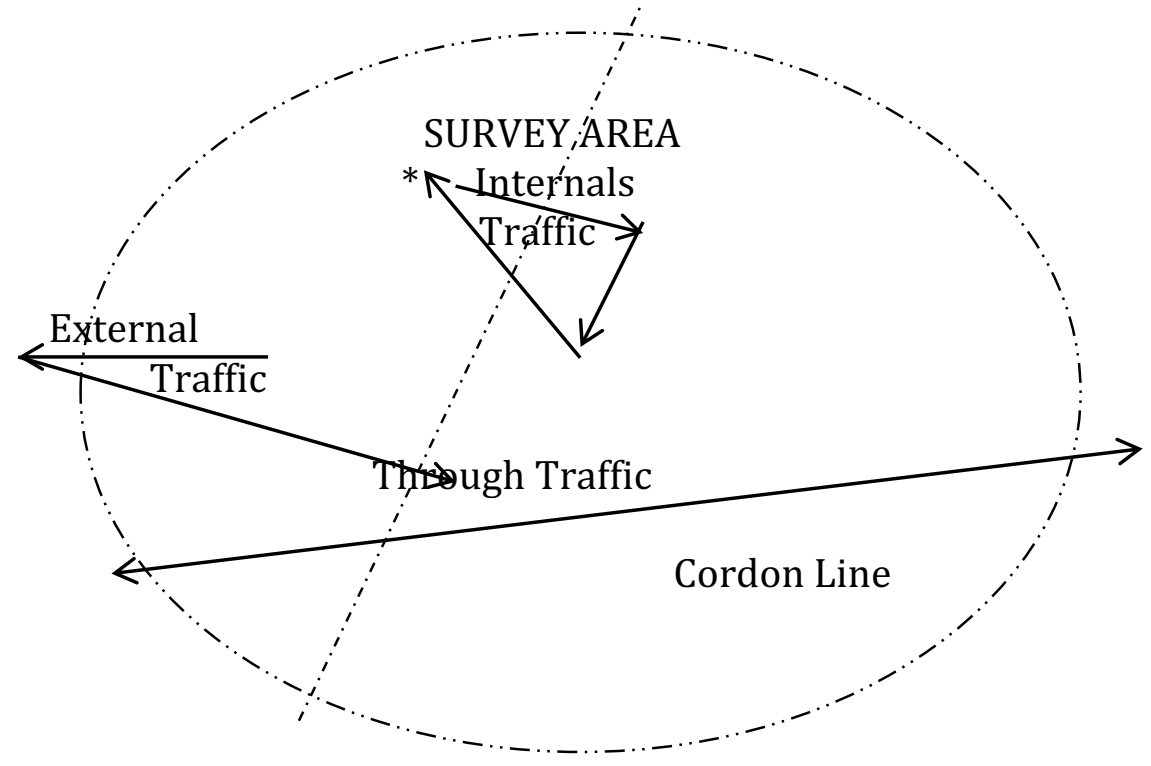

Fig. 2: Categories of traffic within a metropolitan area Adapted \& modified from: Daniel, (2012)

Furthermore, distinctions are usually made in transportation planning circle between public and private modes of transport. In other words, vehicles can be classified on the basis of ownership to determine whether they are publicly owned or privately owned. A distinction could also be made on the basis of the types or category of the vehicle used, namely; cars, buses, lorries, trailers etc. (Okoko 2006). The study has adopted this later basis of classification. The various categories of the urban transport system considered in the study are discussed below.

\section{Pedestrian}

A pedestrian is a person traveling on foot, whether walking or running. Those moving with wheelchairs are also included as pedestrians. The term usually refers to someone walking on a road or pavement,

\section{Bicycle}

A bicycle, often called a bike or cycle, is a human-powered, pedal-driven, single-track vehicle, having two wheels attached to a frame, one behind the other. A bicycle rider is called a cyclist, or bicyclist. Bicycles were introduced in the 19th century in Europe and as of 2003, more than 1 billion have been produced worldwide, twice as many as the number of automobiles that have been produced. They form an insignificant means of intra - city transportation in Nigerian cities, but provides a popular form of recreation, and have been adapted for use as children's toys, general fitness, military and police applications, courier services, and bicycle racing (Wikipedia, 2016).

\section{Motorcycles}

A motorcycle (also called a motorbike, bike, or cycle) is a two wheeled motor vehicle. This is an informal means of urban transport that has gained a considerable quantum of ascendancy and has now become very popular in recent years in Nigerian towns (Foale, 2006).

\section{Tricycles}

Motorized tricycles are three-wheeled vehicles based on the same technology as bicycles or motorcycles, and powered by electric motors, motorcycle, scooter or car engines. Tricycles have a "step-through" seating style, in which the driver sits on a more chair-like seat, with the 
legs together; as well as automatic transmissions (Steve, 2011). Motorcycles conveniently carry only one passenger, tricycles conveniently carry three passengers. Tricycle as a means of transport is recently introduced in Nigeria and has become a preferred intra - urban transport means in many urban centres.

\section{Motor Car}

A car is a wheeled, self-powered motor vehicle used for transportation and a product of the automotive industry. Most definitions of the term specify that cars are designed to run primarily on roads, to have seating for one to eight people, to typically have four wheels with tyres, and to be constructed principally for the transport of people rather than goods. The year 1886 is regarded as the birth year of the modern car. In that year, German inventor Karl Benz built the Benz Patent-Motorwagen. Cars did not become widely available until the early 20th century. One of the first cars that was accessible to the masses was the 1908 Model T, an American car manufactured by the Ford Motor Company. Cars were rapidly adopted in the United States of America, where they replaced animal-drawn carriages and carts, but took much longer to be accepted in Western Europe and other parts of the world. Cars are equipped with controls used for driving, parking, passenger comfort and safety, and controlling a variety of lights. Over the decades, additional features and controls have been added to vehicles, making them progressively more complex. Examples include rear reversing cameras, air conditioning, navigation systems, and in car entertainment. Most cars in use in the 2010s are propelled by an internal combustion engine, fueled by deflagration of gasoline (also known as petrol) or diesel. Both fuels cause air pollution and are also blamed for contributing to climate change and global warming. Vehicles using alternative fuels such as ethanol flexible-fuel vehicles and natural gas vehicles are also gaining popularity in some countries. Electric cars, which were invented early in the history of the car, began to become commercially available in 2008. The history of motor car in Nigeria started earlier before Ngeria as a country had her independence in 1960. The Western world introduced the use of motor car to Nigeria when oil was booming in the 1970s (Chamberlain \& Ede, 2013).

\section{Motorbuses}

Motorbuses are the most widely used of all the public means of transport in many cities of the world. There are different types of motorbuses and these include articulated buses, doubledecker buses, standard or luxurious buses and mini or midi - buses.. Articulated buses were not popular in Nigeria during the colonial period. Only one London transport company, Armeh Transport Limited operated an articulated bus that carried passengers and mails to and from the major cities of Calabar, Onistha - Benein - Lagos etc. Double - decker buses are masstransit motorbuses commonly found in British Towns. Standard buses or luxurious buses generally have a sitting capacity of about $60-100$ passengers. This type is common in Nigeria and is used mostly for inter-state and inter-city rather than intra-city transport. The mini buses have capacity for 27 - 30 passengers. They include Hiace, Liteace, and Urvan etc. this is the type that is common in most Nigerian cities (Okoko, 2006).

\section{Commercial Trucks}

The commercial truck classification is determined based on the vehicle's gross vehicle weight rating (GVWR). The classes range from 1-8. Trucks are also classified more broadly by the Department of Transportation's Federal Highway Administration (FHWA), which groups classes 1-3 as light duty, 4-6 as medium duty, and 7-8 as heavy duty (Wikipedia, 2016).

\section{THE RESEARCH METHODS}

Data for the study was generated through manual traffic count at three (3) traffic cordon points (TCP) carefully determined (see Fig. 3). Field assistants were trained and used for the 
traffic survey. The survey was conducted simultaneously at the three cordon points. Traffic data were generated on week days during the hours of $8 \mathrm{am}-5 \mathrm{pm}$ at hourly intervals. The field assistants were scheduled on rotational and shifting basis. A total of 189 field data sheets were completed and returned and used in the analysis. The traffic was categorized under: (i) Pedestrian, (ii) Bicycle, (iii) Motor cycle, (iv) Tricycle, (v) Buses and Cars, (vi) Heavy duty and trucks. Analyses were done using tabulation, addition, multiplication and division methods. Mapping method included geographic information systems and global positioning system.

\section{THE RESULTS AND DISCUSSION}

\section{Traffic volume and Characteristics}

Traffic volume generated by the six means of the city road transportation is displayed in Table 1 and Figure 4. They show the dominance of motorcycle as a major means of transportation in this city generating traffic volume of 49292 (69.94\%). This is followed by Buses and cars 14324 (20.32\%); Pedestrian 5504 (7.8\%); Heavy duty vehicles/trucks 1221 (1.73\%); Tricycle 70 (0\%); and Bicycle 69(0\%). 


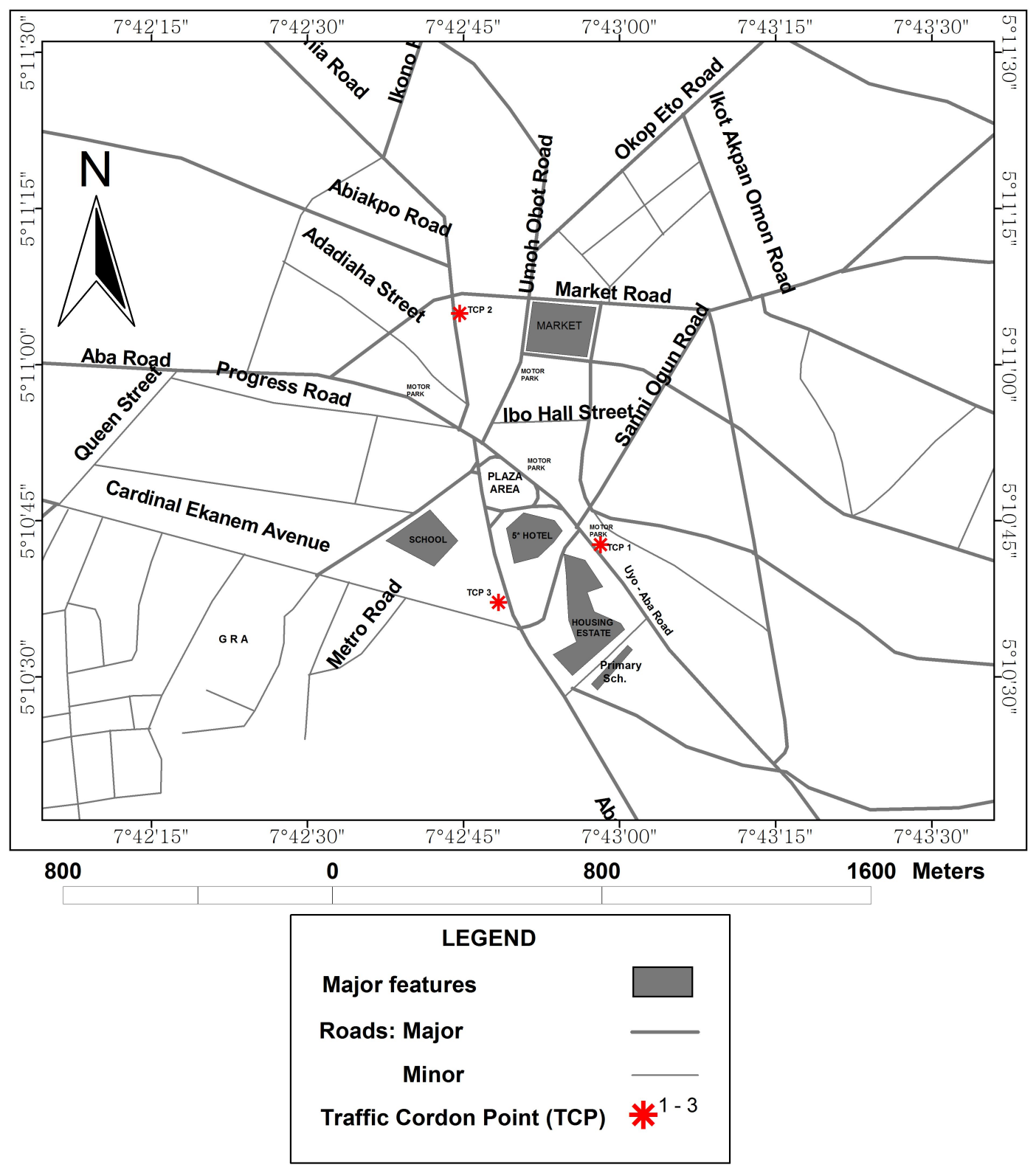

Fig. 3: Ikot Ekpene Urban showing the Locations of Traffic Cordon Points (TCPs)

\section{Spatial Variation of the Total Traffic Volume}

Table 1 and Figure 4 show the summary of the volume of traffic collected on the three cordon points. Out of the total traffic volume of 70480, the highest traffic volume of 25314 (35.92\%) was recorded in Aba road location, followed by Umuahia road with 22807 (32.36\%) and Abak road with $22359(31.72 \%)$. 
Table 1: Total Traffic Volume per location

\begin{tabular}{|l|l|l|l|l|}
\hline Category & Umuahia Rd & Abak Rd & Aba Road & Total \\
\hline Motor cycle & 14552 & 17658 & 17082 & $\begin{array}{l}49292 \\
(69.94 \%)\end{array}$ \\
\hline Pedestrian & 2141 & 795 & 2568 & $\begin{array}{l}5504 \\
(7.81 \%)\end{array}$ \\
\hline Heavy duty/ trucks & 437 & 224 & 560 & $\begin{array}{l}1221 \\
(1.73 \%)\end{array}$ \\
\hline Tricycle & 16 & 24 & 30 & $\begin{array}{l}70 \\
(00 \%)\end{array}$ \\
\hline Buses \& Cars & 5615 & 3643 & 5066 & $\begin{array}{l}14324 \\
(20.32 \%)\end{array}$ \\
\hline Bicycle & 46 & 15 & 8 & $\begin{array}{l}69 \\
(00 \%)\end{array}$ \\
\hline Total & $\begin{array}{l}22807 \\
(32.36 \%)\end{array}$ & $\begin{array}{l}22359 \\
(31.72 \%)\end{array}$ & $\begin{array}{l}25314 \\
(35.92 \%)\end{array}$ & \begin{tabular}{l}
$70480(100 \%)$ \\
\hline
\end{tabular}
\end{tabular}

Authors' fieldwork (2015)

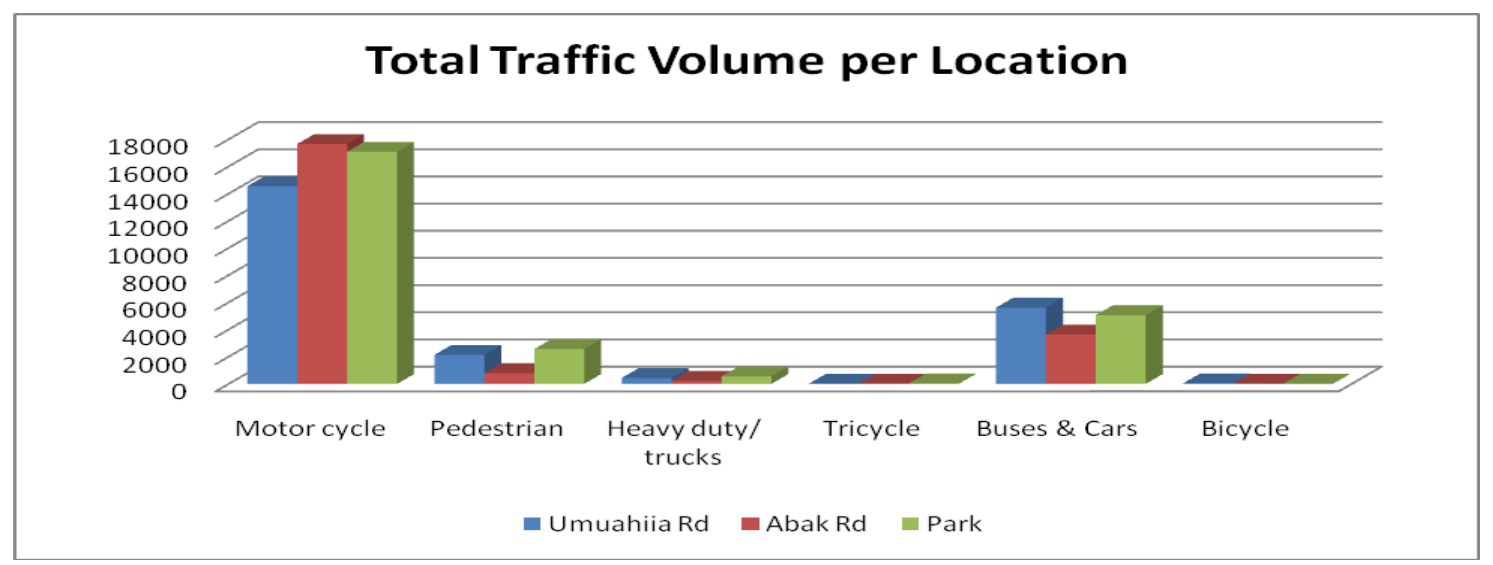

Fig. 4 : Total Traffic Volume per Location Authors' fieldwork (2015)

Table 2 : Temporal Variation of Traffic Volume

\begin{tabular}{|c|c|c|c|c|c|c|c|c|c|c|}
\hline $\begin{array}{l}\text { Ikot } \\
\text { Ekpene }\end{array}$ & $\begin{array}{l}8-9 \\
\text { am }\end{array}$ & $\begin{array}{l}9-10 \\
\text { am }\end{array}$ & $\begin{array}{l}10-11 \\
\mathrm{am}\end{array}$ & $\begin{array}{l}11-12 \\
\text { noon }\end{array}$ & $\begin{array}{l}12-1 \\
\text { pm }\end{array}$ & $\begin{array}{l}1-2 \\
\text { pm }\end{array}$ & $2-3 \mathrm{pm}$ & 3-4 pm & $4-5 \mathrm{pm}$ & Total \\
\hline $\begin{array}{l}\text { Motor } \\
\text { cycle }\end{array}$ & 7918 & 7818 & 5838 & 5071 & 4053 & 4442 & 4785 & 4356 & 5011 & $\begin{array}{l}49292 \\
(69.94 \%)\end{array}$ \\
\hline $\begin{array}{l}\text { Pedestria } \\
\mathrm{n}\end{array}$ & 751 & 731 & 620 & 684 & 505 & 465 & 733 & 557 & 458 & $\begin{array}{l}5504 \\
(7.81 \%)\end{array}$ \\
\hline $\begin{array}{l}\text { Heavy } \\
\text { duty and } \\
\text { trucks }\end{array}$ & 111 & 123 & 136 & 151 & 133 & 128 & 125 & 129 & 185 & $\begin{array}{l}1221 \\
(1.73 \%)\end{array}$ \\
\hline Tricycle & 17 & 9 & 7 & 8 & 2 & 5 & 7 & 10 & 5 & $\begin{array}{l}70 \\
(00 \%)\end{array}$ \\
\hline $\begin{array}{l}\text { Buses \& } \\
\text { Cars }\end{array}$ & 1427 & 1474 & 1509 & 1701 & 1464 & 1948 & 1672 & 1574 & 1555 & $\begin{array}{l}14324 \\
(20.32 \%)\end{array}$ \\
\hline Bicycle & 13 & 8 & 6 & 6 & 7 & 4 & 2 & 13 & 10 & $\begin{array}{l}69 \\
(00 \%)\end{array}$ \\
\hline TOTAL & $\begin{array}{l}10237 \\
(14.53 \\
\%)\end{array}$ & $\begin{array}{l}1016 \\
3 \\
(14.4 \\
2 \%)\end{array}$ & $\begin{array}{l}8116 \\
(11.52 \\
\%)\end{array}$ & $\begin{array}{l}7621 \\
(10.81 \\
\%)\end{array}$ & $\begin{array}{l}6164 \\
(8.75 \\
\%)\end{array}$ & $\begin{array}{l}6992 \\
(9.92 \\
\%)\end{array}$ & $\begin{array}{l}7324 \\
(10.39 \\
\%)\end{array}$ & $\begin{array}{l}6639 \\
(9.42 \%)\end{array}$ & $\begin{array}{l}7224 \\
(10.25 \\
\%)\end{array}$ & $\begin{array}{l}70480 \\
(100 \%)\end{array}$ \\
\hline
\end{tabular}




\section{Temporal Variation of Traffic Volume}

Table 2 shows the temporal variation of the total traffic volume in the study area. The survey has shown a general high traffic in the various sections. Nevertheless peaks were observed in the categories throughout the day. The survey reveals peak volume in motorcycle recorded in the morning hours of 8-9 am but declined steadily till about $2 \mathrm{pm}$ and picked up again at 4$5 \mathrm{pm}$.

Table 3: Weekday Traffic Volume along Umuahia Road

\begin{tabular}{|c|c|c|c|c|c|c|c|c|c|c|c|}
\hline & & $8-9$ & $9-10$ & $10-11$ & $11-12$ & $12-1$ & $1-2$ & $2-3$ & $3-4$ & $4-5$ & Total \\
\hline \multirow[t]{3}{*}{$\begin{array}{l}\text { Motor } \\
\text { cycle }\end{array}$} & $\begin{array}{l}\text { From } \\
\text { Plaza }\end{array}$ & 1290 & 1178 & 860 & 912 & 902 & 830 & 875 & 992 & 1013 & 8852 \\
\hline & To Plaza & 835 & 1055 & 615 & 520 & 460 & 485 & 665 & 520 & 545 & 5700 \\
\hline & Total & 2125 & 2233 & 1475 & 1432 & 1362 & 1315 & 1540 & 1512 & 1558 & $\begin{array}{r}1455 \\
2\end{array}$ \\
\hline \multirow[t]{3}{*}{$\begin{array}{l}\text { Pedestr } \\
\text { ian }\end{array}$} & $\begin{array}{l}\text { From } \\
\text { Plaza } \\
\end{array}$ & 200 & 239 & 158 & 113 & 116 & 125 & 137 & 149 & 105 & 1342 \\
\hline & To Plaza & 65 & 88 & 92 & 111 & 63 & 96 & 85 & 109 & 90 & 799 \\
\hline & Total & 265 & 327 & 250 & 224 & 179 & 221 & 222 & 258 & 195 & 2141 \\
\hline \multirow{3}{*}{$\begin{array}{l}\text { Heavy } \\
\text { duty } \\
\text { and } \\
\text { trucks }\end{array}$} & $\begin{array}{l}\text { From } \\
\text { Plaza }\end{array}$ & 18 & 30 & 26 & 37 & 21 & 24 & 10 & 11 & 14 & 191 \\
\hline & To Plaza & 29 & 19 & 22 & 21 & 33 & 21 & 30 & 25 & 46 & 246 \\
\hline & Total & 47 & 49 & 48 & 58 & 54 & 45 & 40 & 36 & 60 & 437 \\
\hline \multirow[t]{3}{*}{ Keke } & $\begin{array}{l}\text { From } \\
\text { Plaza }\end{array}$ & 1 & 0 & 1 & 3 & 0 & 1 & 1 & 2 & 1 & 10 \\
\hline & To Plaza & 2 & 1 & 1 & 1 & 0 & 0 & 0 & 1 & 0 & 6 \\
\hline & Total & 3 & 1 & 2 & 4 & 0 & 1 & 1 & 3 & 1 & 16 \\
\hline \multirow[t]{3}{*}{$\begin{array}{l}\text { Buses \& } \\
\text { Cars }\end{array}$} & $\begin{array}{l}\text { From } \\
\text { Plaza }\end{array}$ & 204 & 374 & 394 & 536 & 358 & 427 & 351 & 313 & 243 & 3200 \\
\hline & To Plaza & 427 & 216 & 224 & 173 & 267 & 379 & 223 & 233 & 273 & 2415 \\
\hline & Total & 631 & 590 & 618 & 709 & 625 & 806 & 574 & 546 & 516 & 5615 \\
\hline \multirow[t]{4}{*}{ Bicycle } & $\begin{array}{l}\text { From } \\
\text { Plaza }\end{array}$ & 4 & 6 & 0 & 3 & 4 & 2 & 1 & 5 & 3 & 28 \\
\hline & To Plaza & 0 & 2 & 5 & 3 & 2 & 1 & 0 & 3 & 2 & 18 \\
\hline & Total & 4 & 8 & 5 & 6 & 6 & 3 & 1 & 8 & 5 & 46 \\
\hline & $\begin{array}{l}\text { GRAND } \\
\text { TOTAL }\end{array}$ & 3075 & 3208 & 2398 & 2433 & 2226 & 2391 & 2378 & 2363 & 2335 & $\begin{array}{r}2280 \\
7\end{array}$ \\
\hline
\end{tabular}

\section{Authors' fieldwork (2015)}


Table 4: Weekday Traffic Volume along Abak Road

\begin{tabular}{|c|c|c|c|c|c|c|c|c|c|c|c|}
\hline & & $8-9$ & $9-10$ & $10-11$ & $11-12$ & $12-1$ & $1-2$ & $2-3$ & $3-4$ & $4-5$ & Total \\
\hline \multirow[t]{3}{*}{$\begin{array}{l}\text { Motor } \\
\text { cycle }\end{array}$} & $\begin{array}{l}\text { From } \\
\text { Plaza }\end{array}$ & $\begin{array}{r}115 \\
0\end{array}$ & 955 & 635 & 605 & 501 & 660 & 1130 & 805 & 595 & 7036 \\
\hline & To Plaza & $\begin{array}{r}259 \\
5\end{array}$ & 2065 & 1755 & 1080 & 660 & 665 & 726 & 491 & 585 & 10622 \\
\hline & Total & $\begin{array}{r}374 \\
5\end{array}$ & 3020 & 2390 & 1685 & 1161 & $\begin{array}{r}132 \\
5\end{array}$ & 1856 & 1296 & 1180 & 17658 \\
\hline \multirow[t]{3}{*}{$\begin{array}{l}\text { Pedestr } \\
\text { ian }\end{array}$} & $\begin{array}{l}\text { From } \\
\text { Plaza }\end{array}$ & 60 & 34 & 19 & 37 & 37 & 30 & 20 & 30 & 24 & 291 \\
\hline & To Plaza & 55 & 34 & 22 & 34 & 41 & 29 & 225 & 39 & 25 & 504 \\
\hline & Total & 115 & 68 & 41 & 71 & 78 & 59 & 245 & 69 & 49 & 795 \\
\hline \multirow{3}{*}{$\begin{array}{l}\text { Heavy } \\
\text { duty } \\
\text { and } \\
\text { trucks }\end{array}$} & $\begin{array}{l}\text { From } \\
\text { Plaza }\end{array}$ & 14 & 16 & 19 & 12 & 5 & 8 & 9 & 18 & 11 & 112 \\
\hline & To Plaza & 17 & 12 & 11 & 11 & 11 & 12 & 6 & 15 & 17 & 112 \\
\hline & Total & 31 & 28 & 30 & 23 & 16 & 20 & 15 & 33 & 28 & 224 \\
\hline \multirow[t]{3}{*}{ Keke } & $\begin{array}{l}\text { From } \\
\text { Plaza }\end{array}$ & 7 & 0 & 2 & 1 & 2 & 0 & 0 & 1 & 0 & 13 \\
\hline & To Plaza & 4 & 1 & 1 & 2 & 0 & 1 & 1 & 1 & 0 & 11 \\
\hline & Total & 11 & 1 & 3 & 3 & 2 & 1 & 1 & 2 & 0 & 24 \\
\hline \multirow[t]{3}{*}{$\begin{array}{l}\text { Buses \& } \\
\text { Cars }\end{array}$} & $\begin{array}{l}\text { From } \\
\text { Plaza }\end{array}$ & 175 & 167 & 199 & 166 & 167 & 315 & 246 & 215 & 259 & 1909 \\
\hline & To Plaza & 225 & 193 & 150 & 235 & 150 & 151 & 260 & 200 & 170 & 1734 \\
\hline & Total & 400 & 360 & 349 & 401 & 317 & 466 & 506 & 415 & 429 & 3643 \\
\hline \multirow[t]{4}{*}{ Bicycle } & $\begin{array}{l}\text { From } \\
\text { Plaza }\end{array}$ & 4 & 0 & 1 & 0 & 0 & 0 & 0 & 1 & 4 & 10 \\
\hline & To Plaza & 5 & 0 & 0 & 0 & 0 & 0 & 0 & 0 & 0 & 5 \\
\hline & Total & 9 & 0 & 1 & 0 & 0 & 0 & 0 & 1 & 4 & 15 \\
\hline & $\begin{array}{l}\text { GRAND } \\
\text { TOTAL }\end{array}$ & $\begin{array}{r}431 \\
1\end{array}$ & 3477 & 2814 & 2183 & 1574 & $\begin{array}{r}187 \\
1\end{array}$ & 2623 & 1816 & 1690 & 22359 \\
\hline
\end{tabular}

Authors' fieldwork (2015) 
Daniel, E. E., Udoh, J., \& Udo, R. K. (2017). Intra - Urban Traffic Characteristics Of Ikot Ekpene - An Emerging Urban Centre In Akwa Ibom State, Nigeria. Advances in Social Sciences Research Journal, 4(17) 215-224.

Table 5: Weekday Traffic Volume along Aba Road

\begin{tabular}{|c|c|c|c|c|c|c|c|c|c|c|c|}
\hline & & $8-9$ & $9-10$ & $10-11$ & $11-12$ & $12-1$ & $1-2$ & $2-3$ & $3-4$ & $4-5$ & Total \\
\hline \multirow[t]{3}{*}{$\begin{array}{l}\text { Motor } \\
\text { cycle }\end{array}$} & $\begin{array}{l}\text { From } \\
\text { Plaza }\end{array}$ & 748 & 765 & 723 & 704 & 780 & 752 & 759 & 708 & 1023 & 6962 \\
\hline & To Plaza & 1300 & 1800 & 1250 & 1250 & 750 & 1050 & 630 & 840 & 1250 & $\begin{array}{l}1012 \\
0\end{array}$ \\
\hline & Total & 2048 & 2565 & 1973 & 1954 & 1530 & 1802 & 1389 & 1548 & 2273 & $\begin{array}{r}1708 \\
2 \\
\end{array}$ \\
\hline \multirow[t]{3}{*}{$\begin{array}{l}\text { Pedestr } \\
\text { ian }\end{array}$} & $\begin{array}{l}\text { From } \\
\text { Plaza }\end{array}$ & 327 & 280 & 255 & 277 & 173 & 127 & 145 & 144 & 96 & 1824 \\
\hline & To Plaza & 44 & 56 & 74 & 112 & 75 & 58 & 121 & 86 & 118 & 744 \\
\hline & Total & 371 & 336 & 329 & 389 & 248 & 185 & 266 & 230 & 214 & 2568 \\
\hline \multirow{3}{*}{$\begin{array}{l}\text { Heavy } \\
\text { duty } \\
\text { and } \\
\text { trucks }\end{array}$} & $\begin{array}{l}\text { From } \\
\text { Plaza }\end{array}$ & 22 & 17 & 24 & 21 & 23 & 23 & 20 & 28 & 51 & 229 \\
\hline & To Plaza & 11 & 29 & 34 & 49 & 40 & 40 & 50 & 32 & 46 & 331 \\
\hline & Total & 33 & 46 & 58 & 70 & 63 & 63 & 70 & 60 & 97 & 560 \\
\hline \multirow[t]{3}{*}{ Keke } & $\begin{array}{l}\text { From } \\
\text { Plaza } \\
\end{array}$ & 2 & 6 & 2 & 1 & 0 & 0 & 3 & 3 & 0 & 17 \\
\hline & To Plaza & 1 & 1 & 0 & 0 & 0 & 3 & 2 & 2 & 4 & 13 \\
\hline & Total & 3 & 7 & 2 & 1 & 0 & 3 & 5 & 5 & 4 & 30 \\
\hline \multirow[t]{3}{*}{$\begin{array}{l}\text { Buses \& } \\
\text { Cars }\end{array}$} & $\begin{array}{l}\text { From } \\
\text { Plaza }\end{array}$ & 216 & 228 & 247 & 236 & 270 & 281 & 246 & 254 & 283 & 2261 \\
\hline & To Plaza & 180 & 296 & 295 & 355 & 252 & 395 & 346 & 359 & 327 & 2805 \\
\hline & Total & 396 & 524 & 542 & 591 & 522 & 676 & 592 & 613 & 610 & 5066 \\
\hline \multirow[t]{3}{*}{ Bicycle } & $\begin{array}{l}\text { From } \\
\text { Plaza } \\
\end{array}$ & 0 & 0 & 0 & 0 & 1 & 1 & 1 & 4 & 1 & 8 \\
\hline & To Plaza & 0 & 0 & 0 & 0 & 0 & 0 & 0 & 0 & 0 & 0 \\
\hline & Total & 0 & 0 & 0 & 0 & 1 & 1 & 1 & 4 & 1 & 8 \\
\hline 7 & $\begin{array}{l}\text { GRAND } \\
\text { TOTAL }\end{array}$ & 9524 & 9644 & 7700 & 7173 & 5721 & 6298 & 6653 & 6180 & 6863 & $\begin{array}{r}6575 \\
6 \\
\end{array}$ \\
\hline
\end{tabular}

Authors' fieldwork (2015)

The intra-city Traffic Interaction pattern

Tables 3, 4 and 5 show the volume of traffic interaction among the three major roads (Uyo - Aba Road, Abak - Ikot Ekpene Road, Ikot Ekpene - Umuahia Road) and the city centre popularly refered as 'Ikot Ekpene Plaza'. Motorcycle records the highest volume of interaction among the roads and the plaza, with 49,292 weekly total. Buses and Cars recorded 14,324 total weekly volume of interaction. This number includes inter-city traffic from Umuahia, Aba, Uyo, Calabar, Abak and other interrelated urban centres in the region. The same is true of the Heavy duty and Truck category of traffic which recorded a total of 1221 volume of interaction with the city centre.

\section{DISCUSSION}

In this study, attempts have been made to determine the volume and characteristics, spatial variations, temporal variation and the interaction patterns of traffic movements in Ikot Ekpene municipality. The findings revealed motor cycle as the dominant and most preferred means of transportation in this city. Unlike Uyo, the State Capital and many other cities in Nigeria that had banned the use of motorcycle, it is still being used here. The very high volume of motor cycle traffic is an indication that the motorcycle operators chased out of Uyo, the State Capital and other cities have found Ikot Ekpene a safe ground of free operation. But the heavy motorcycle movements at the city centre are very unsafe for the cyclists and their passengers, because they are prone to quick fall. They also constitute hazards to other motorists and 
pedestrians, because they are noted for careless operation characters. It is also difficult to regulate and control their operations since most of them are not trained and so are not licensed to operate vehicles on the road (FRSC, 2008). Cars and buses category took the second place. These, serve mostly the inter - city and inter - state transport needs rather than intra-city transport need of Ikot Ekpene, since the city also serves as a transit city for vehicular traffic connecting other parts of the state and the country. The traffic movements 'to' and 'fro' Uyo and Calabar pass through Ikot Ekpene. A balanced traffic flow was observed in all the locations by total volume generated, but there was slight edge Aba road has over the other two locations (Umuahia Road and Abak Road), showing the importance of Aba Road as a significant inter-city route connecting Uyo and other urban centres in Akwa Ibom State and Calabar, Cross River State. However, this 'through traffic' analysis was not considered in this study. Regarding the temporal variation of traffic movements in the city, two peak periods observed ( 8 - 9am and $4-5 \mathrm{pm}$ ) coincide with the morning rush hours when workers commute to work and the evening when they return back home.

\section{CONCLUSION}

The traffic situation in Ikot Ekpene Urban centre is very uniqe in Akwa Ibom state. As a nodal city, it provides inter-state transportation links with multiple states of the federation including Abia, Imo and Cross River states as well as inter-urban links with multiple Local Government Headquarters of the State. The city is interacted by all types traffic; inter-state, inter-city and the intra-city traffic. The study has identified the various categories and characteristics of traffic in the city weekly. It has thus provided a basis for planning the transport operation in the city. The policy makers will find the study a useful guide for the formulation of rational transportation related policy decisions for the area. To the researchers, the study has provided the basis for comparing the traffic characteristics of this urban centre with other urban centres in the world.

\section{RECOMMENDATIONS}

1. Bye-passes or ring roads should be constructed to divert the inter-state and inter-urban traffic from the city centre. Thus, the traffic 'to' and 'from' other regional urban centres can effectively and freely interact with Ikot Ekpene without affecting the free flow of intra-city traffic.

2. To bring serenity and orderly traffic atmosphere to Ikot Ekpene city, the operation of commercial motorcyclists should be regulated and controlled by limiting their routes of operation away from the city centre. They must also be compelled to observe safety rules and Highway Code in their operation. This will protect the lives of the operators themselves, their passengers and other road users.

3. The public and private commercial motor parks should be relocated from the city centre to the outer ring of the city. This will allow for free and smooth operations of the intracity taxi services and private vehicular movements.

4. The existing urban roads and streets should be upgraded to provide the pedestrian walk ways. This will save the pedestrians, bicycle and wheelchair users the risk of competing for road space with vehicular traffic.

\section{References}

Adeniji, S. A. (1981): Public Transport and Urban Development Strategy in Nigeria. Unpublished Ph.D. Thesis, University of Wales.

Chamberlain, O. and Ede, E (2013). History of Automobile Past and Present Challenges Facing Automobile Production in Nigeria. Journal of Research and Methods in Education, 2(4): 11-16. 
Daniel, E. (2005). Trip Generation Models in A Developing City of Nigeria. International Journal of Social Sciences, 4(1): 1-19.

Daniel, E. (2012), Inter-Urban Transportation Patterns in a Sub-Region of Nigeria: An Analysis. Germany: Lap Lambert Academic Publishing.

Daniel, E. and Ituen, U. (2013a). Inter-Urban Trip Generation Models for the Urban Centres in Akwa Ibom State, Nigeria. Civil and Environmental Research, 3 (4): 55-62.

Daniel, E. and Ituen, U. (2013b). Inequality in the Trip Patterns among Urban Centres in Nigeria: A Case of Akwa Ibom State. International Journal of Development Studies. Vol.7 No. 6 May, 2013: pp. 58 - 69.

Daniel, E. and Umoren, V. (2013). Spatial Variation and Determinants of Interaction among Urban Centres in Akwa Ibom State, Nigeria. European Journal of Hospitality and Tourism Research (United Kingdom), 1 (2): 1-11.

Eluwa, S.; Ajagbe, M.; Umaru, T.; Ojo, A.; Yusuf, G. (2012). Assessing Intra-City Road Traffic in An Indigenous African City, Ibadan, Nigeria. Engineering Science and Technology: Vol. 2, No. 2. Pp. 221 - 228.

Foale, Tony (2006). Motorcycle Handling and Chassis Designed. Tony Foale Designs. Pp. 1-4.

Nair, Kaanan K. (1972). Politics and Society in South Eastern Nigeria, 1841 - 1906, London, Frank Cass.

Federal Road Safety Commission (2008). Federal Highway Code. Nigeria, Detail Works Ltd.

Okoko, E. (2006) Urban Transportation Planning and Modelling. Nigeria. Millenium Publishers.

Steve, Greene (2011). Free on Three; The wild World of Human Powered Recumbent Tadpole Tricycles. iUniverse, p. 21.

The World Bank (2016): data. Worldbank.org retrieved June, 162016.

Umoren, V. E., Daniel, E. and Akpan, E. S. (2010). Analysis of Road Transport Infrastructure Network in Akwa Ibom State, Nigeria. In: Usoro, E. and Akpan, P. (Eds.) Akwa Ibom State: A Geographic Perspective. Enugu, Nigeria: Immaculate Pub. Ltd., pp. 215 - 224.

White, P. R. (1976): Planning for Public Transport. London. Hutchinson

Wikipedia (2016): Free Online Encyclopedia; Retrieved June 17, 2016. 